\title{
Isolation and characterization of polymorphic
} microsatellite markers for the chub mackerel (Scomber japonicus) and cross-species amplification in the blue mackerel (S. australasicus)

\author{
F.F. Chen ${ }^{1,2}$, C.Y. Ma ${ }^{1}$, L.P. Yan ${ }^{1}$, H. Zhang ${ }^{1}$, W. Wang ${ }^{1}$, Y. Zhang ${ }^{1}$ and L.B. Ma ${ }^{1}$ \\ ${ }^{1}$ Key Laboratory of the East China Sea and Oceanic Fishery Resources Exploitation, \\ Ministry of Agriculture, East China Sea Fisheries Research Institute, \\ Chinese Academy of Fishery Sciences, Shanghai, China \\ ${ }^{2}$ College of Fisheries and Life Science, Shanghai Ocean University, Shanghai, China \\ Corresponding authors: C.Y. Ma / L.B. Ma \\ E-mail: mcy0527@126.com / malingbo@vip.sina.com
}

Genet. Mol. Res. 16 (3): gmr16039712

Received May 4, 2017

Accepted July 21, 2017

Published August 17, 2017

DOI http://dx.doi.org/10.4238/gmr16039712

Copyright $(2017$ The Authors. This is an open-access article distributed under the terms of the Creative Commons Attribution ShareAlike (CC BY-SA) 4.0 License.

\begin{abstract}
In this study, 10 polymorphic microsatellite markers were developed in Scomber japonicus and were examined on 30 individuals collected from the North Pacific. The number of alleles per locus ranged from 4 to 17 . The observed and expected heterozygosities per locus ranged from 0.2759 to 0.8621 and from 0.43071 to 0.9177 , respectively. The polymorphism information content (PIC) was from 0.3931 to 0.8939 . One locus showed moderate polymorphism $(0.25<$ PIC < 0.5), while the rest were highly polymorphic (PIC > 0.5). Two loci showed significant deviation from Hardy-Weinberg equilibrium after Bonferroni corrections $(\mathrm{P}<0.005)$. No linkage disequilibrium was detected among the loci. Results of cross-species amplification showed that 10 microsatellite markers were successfully amplified in 29 individuals of $S$. australasicus and 9 indicated polymorphisms. These markers will be useful for investigating the genetic structure, gene
\end{abstract}

Genetics and Molecular Research 16 (3): gmr16039712 
flow, and species identification of S. japonicus and S. australasicus, its closely related species.

Key words: Microsatellite markers; Genetic diversity; Cross-species amplification; Scomber japonicus

\section{INTRODUCTION}

The chub mackerel (Scomber japonicus) is a widespread pelagic fish in the warm and temperate transition coastal areas and the adjacent seas of Atlantic, Pacific, and Northwest Indian (Collette and Nauen, 1983; Zeng et al., 2012). S. japonicus served as the global marine capture fishery production and provided stability for coastal systems (FAO, 2010). As one of the most important fishery resources of China, the yield of $S$. japonicus maintained at a higher level. However, the population was already in overfishing situation during the period 1980-2002 (Hua and Shan, 2004). Therefore, S. japonicus are more vulnerable to the impact of marine environment and strong fishing pressure. To protect this important fish resource, it is necessary to take knowledge of its population structure, gene flow levels, and genetic diversity (Utter, 2006; Cha et al., 2010). However, we know little about its ecological genetics and evolutionary biology.

Microsatellites, widely existing along the eukaryotic genome (Weber and May, 1989; O'Reilly and Wright, 1995), are popular genetic markers because of high polymorphism, ease of genotyping, and co-dominant inheritance (Sun et al., 2009). Moreover, they have been widely developed and used in the study of population genetics of many species (Guo et al., 2016; Mohanty et al., 2016; Tan et al., 2016). Furthermore, some of these microsatellite markers developed for Scomber species have been successfully used for amplification in other related species (Tang et al., 2009; Divya et al., 2016). However, it is not very sufficient, and some locus-by-population tests exhibited significant departure from Hardy-Weinberg equilibrium (HWE) (Cheng et al., 2015). So it is necessary to isolate more microsatellite markers for the utility of the population genetic study.

Scomber australasicus is one of the close species of S. japonicus and differ in a series of morphologic characters, including sculpturing of the skull, the number of precaudal vertebrae, the arrangement of palatine teeth, and the number of first dorsal spines (Matsui, 1967). S. australasicus inhabits the west Pacific and the southeast Indian Oceans.

It is known that the RAPD fragments contain rich microsatellites (Cifarelli et al., 1995; Ender et al., 1996). In the present study, we isolated 10 novel polymorphic microsatellite markers in S. japonicus using the RAPD-PCR method (Lunt, 1999). These markers provided a useful tool for investigating the genetic structure and species identification of $S$. japonicus and its closely related species.

\section{MATERIAL AND METHODS}

\section{Sample collection and DNA extraction}

Our project was approved by the East China Sea Fisheries Research Institute. The 30 individuals of $S$. japonicus in the present study were collected from the North Pacific $(145.383 \mathrm{E}, 41.083 \mathrm{~N})$. Moreover, 29 individuals of $S$. australasicus were collected from

Genetics and Molecular Research 16 (3): gmr16039712 
the Indian Ocean for the performance of cross-priming tests. Muscle tissues of specimens were preserved in $100 \%$ ethanol at room temperature until DNA extraction. Total Genomic DNA was extracted from muscles using the Animal Genomic DNA Extraction Kit (TianGen, Beijing, China) and stored at $-20^{\circ} \mathrm{C}$ until RAPD was conducted.

\section{Isolation of microsatellite markers}

First, we randomly selected 10 RAPD primers from the catalogue of Sangon Biotech (Shanghai) Co., Ltd. (Table 1) to amplify the target DNA fragments. The PCR amplification was performed in a $25-\mu \mathrm{L}$ total volume containing $12.5 \mu \mathrm{L} 2 \mathrm{X}$ Kod PCR MasterMix, 0.5 $\mu \mathrm{M}$ RAPD primer $(10 \mu \mathrm{M}), 11 \mu \mathrm{L}$ sterilized distilled water and approximately $1 \mu \mathrm{L}$ template DNA. After $5 \mathrm{~min}$ of denaturation at $94^{\circ} \mathrm{C}$, amplification proceeded for 40 cycles $\left(94^{\circ} \mathrm{C}\right.$ for $30 \mathrm{~s}, 37^{\circ} \mathrm{C}$ for $40 \mathrm{~s}, 72^{\circ} \mathrm{C}$ for $45 \mathrm{~s}$ ) and a final extension for $5 \mathrm{~min}$ at $72^{\circ} \mathrm{C}$. Then, the PCR products were cloned using the pMD19-T vector (Takara). The connection system including 1 $\mu \mathrm{L}$ pMD19-T Vector, $4 \mu \mathrm{L}$ of PCR product, and $5 \mu \mathrm{L}$ solution was stored at $16^{\circ} \mathrm{C}$ for reaction for $3 \mathrm{~h}$ and then transferred to $4^{\circ} \mathrm{C}$. Finally, $10 \mu \mathrm{L}$ of fluid connection was transformed into Escherichia coli competent cells (TianGen) and cultivated in plate culture medium at $37^{\circ} \mathrm{C}$ for several hours. The cultivated competent cells were randomly selected for sequencing using the ABI Prism 3730 automated DNA sequencer (PE Corporation). Microsatellite sequences obtained were searched using the SSR Hunter 1.3 software (Qiang and Wan, 2005).

Table 1. Ten RAPD primers used for amplifying the target DNA fragments of Scomber japonicus (the primers were derived from the product catalogue of Sangon Biotechnology Company).

\begin{tabular}{l|l}
\hline Primer name & Primer sequence $\left(5^{\prime}-3^{\prime}\right)$ \\
\hline S1 & GTTTCGCTCC \\
\hline S2 & TGATCCCTGG \\
\hline S3 & CATCCCCCTG \\
\hline S4 & GGACTGGAGT \\
\hline S5 & TGCGCCCTTC \\
\hline S6 & TGCTCTGCCC \\
\hline S7 & GGTGACGCAG \\
\hline S8 & GTCCACACGG \\
\hline S10 & TGGGGGACTC \\
\hline
\end{tabular}

\section{Characteristics and polymorphism assessment}

Firstly, seven individuals of $S$. japonicus were randomly selected to assess the preliminary polymorphism of the microsatellite markers. Moreover, we used 30 individuals of $S$. japonicus to quantify the levels of polymorphism of the 10 loci. The PCR amplification was performed on a Peltier Thermal Cycler in a $25-\mu \mathrm{L}$ total volume, which included $0.75 \mu \mathrm{L}$ of each primer $(10 \mu \mathrm{M}), 2.0 \mu \mathrm{L}$ dNTP $(2.5 \mu \mathrm{M}), 2.5 \mu \mathrm{L}$ 10X PCR buffer $\left(\mathrm{Mg}^{2+}\right.$ plus $), 2.5 \mathrm{U}$ Taq polymerase, $17.5 \mu \mathrm{L}$ sterilized distilled water, and approximately $1 \mu \mathrm{L}$ template DNA under the following conditions: one cycle of denaturation at $94^{\circ} \mathrm{C}$ for $5 \mathrm{~min} ; 30$ cycles of 30 $\mathrm{s}$ at $94^{\circ} \mathrm{C}, 45 \mathrm{~s}$ at a primer-specific annealing temperature, and $1.5 \mathrm{~min}$ at $72^{\circ} \mathrm{C}$. Finally, the products were extended for $7 \mathrm{~min}$ at $72^{\circ} \mathrm{C}$ (Table 1). The PCR products were separated on a $6 \%$ polyacrylamide denaturing gel and visualized by silver staining using a 10-bp DNA ladder marker pBR322/MspI (TianGen).

Genetics and Molecular Research 16 (3): gmr16039712 


\section{Data analysis}

Allele frequency, observed $\left(H_{\mathrm{O}}\right)$ and expected $\left(H_{\mathrm{E}}\right)$ heterozygosities, the chi-square test for HWE, and the linkage disequilibrium (LD) were performed using the Popgene 3.4 software (Raymond and Rousset, 1995). The null-allele frequency was estimated by the MICROCHECKER version 2.2.3 software (Oosterhout et al., 2004). Polymorphism information content (PIC) was calculated by CERVUS 3.0 (Marshall et al., 1998). Significance values for all multiple tests were corrected by sequential Bonferroni procedure (Rice, 1989).

\section{RESULTS AND DISCUSSION}

A total of 1000 clones were randomly selected to be tested by PCR with M13-47 (5'-GGG ATC CTC TAG AGA TT-3') and M13-48 (5'-GCC TGC AGG TCG ACG ATT-3'). Then, 148 positive clones were identified and sequenced using an ABI Prism 3730 automated DNA sequencer. In comparison to other species, the positive clone rate in this study was lower than that in fish (Cynoglossus semilaevis) (Liu et al., 2008) and crab (Scylla paramamosain) (Ma et al., 2010). Moreover, 75 pairs of primers were designed by using Primer Premier 5.0 and synthesized. The preliminary polymorphism assessment of the 75 pairs of microsatellite primers was evaluated by seven individuals, which were randomly picked out from the 30 individuals collected from the North Pacific (145.383E, 41.083N). All primers could lead to successfully PCR amplification, but only 10 of them showed polymorphism. Moreover, the levels of polymorphism of the polymorphic loci were evaluated by 30 individuals collected from the North Pacific (145.383E, 41.083N). Finally, we identified 10 polymorphic microsatellite loci (Table 2).

\begin{tabular}{|c|c|c|c|c|c|}
\hline Loci & GenBank accession No. & Primer sequence $\left(5^{\prime}-3^{\prime}\right)$ & Repeat motif & $\mathrm{Ta}\left({ }^{\circ} \mathrm{C}\right)$ & Allele size range (bp) \\
\hline SJ-23 & KY042106 & $\begin{array}{l}\text { F: GACGACTGACGGAGACGCTT } \\
\text { R: TGCTCAGGGTGTCGCAGTTT }\end{array}$ & $(\mathrm{AG})_{11}$ & 55 & $169-187$ \\
\hline SJ-28 & KY042107 & $\begin{array}{l}\text { F: GATCTAAGAGCAATCAGTCC } \\
\text { R: CAAACCTGACCCAGAATGAT }\end{array}$ & (TG) 8 & 56 & $182-200$ \\
\hline SJ-30 & KY0421078 & $\begin{array}{l}\text { F: GTTTCCCATCTGTCCACCCA } \\
\text { R: AGCAACTTCCTCCGCTTCTG }\end{array}$ & $\begin{array}{l}(\mathrm{TC})_{6} \mathrm{G}(\mathrm{C} \\
\mathrm{T})_{6 \ldots}(\mathrm{CT})_{8}\end{array}$ & 55 & $199-245$ \\
\hline SJ-31 & KY042109 & $\begin{array}{l}\text { F: AGAACCTCCATCCTGAAGCC } \\
\text { R: AAAGCCTAATCCCAAACCGA }\end{array}$ & $(\mathrm{GT})_{5}$ & 56 & $286-300$ \\
\hline SJ-32 & KY042110 & $\begin{array}{l}\text { F: CTCCCCTAACACTCCTTCCC } \\
\text { R: TTTCCCATCTGTCCACCCAG }\end{array}$ & $\begin{array}{c}(\mathrm{GA})_{5} \ldots(\mathrm{GA})_{7} \ldots \\
(\mathrm{GA})_{6} \mathrm{GC}(\mathrm{GA})_{6}\end{array}$ & 55 & $291-325$ \\
\hline SJ-42 & KY042111 & $\begin{array}{l}\text { F: CGTGACAGCAGGCTTAGAGG } \\
\text { R: TGACAGACGGCCTGACAGAT }\end{array}$ & $(\mathrm{GA})_{7} \ldots(\mathrm{AG})_{7}$ & 55 & $222-262$ \\
\hline SJ-45 & KY042112 & $\begin{array}{l}\text { F: TAAAATCATCAAAGACACGCTC } \\
\text { R: CACATCCTCCATTCGGTAAA }\end{array}$ & $(\mathrm{TC})_{5}$ & 54 & $135-163$ \\
\hline SJ-65 & KY042113 & $\begin{array}{l}\text { F: TAGACAGGCAGTCAGATTTCAAC } \\
\text { R: TCATCCCTTCATTTATACAACCC }\end{array}$ & $(\mathrm{AG})_{9}(\mathrm{AC})_{5}$ & 57 & $149-157$ \\
\hline SJ-76 & KY042114 & $\begin{array}{l}\text { F: GCTCAGGGTGTCACAGTTTT } \\
\text { R: TAATCCATGTAATTGCGTTG }\end{array}$ & $(\mathrm{CT})_{13}$ & 55 & $137-213$ \\
\hline SJ-78 & KY042115 & $\begin{array}{l}\text { F: GCATTGAGATGATTTTGGTA } \\
\text { R: GCAGAATTGGGATGGAAATA }\end{array}$ & $(\mathrm{TC})_{5} \ldots(\mathrm{CT})_{7}$ & 53 & $191-227$ \\
\hline
\end{tabular}

$\mathrm{Ta}=$ annealing temperature.

The levels of polymorphism of the 10 loci were qualified in 30 individuals of $S$. japonicus collected from the North Pacific (145.383E, 41.083N). A total of 99 alleles with size ranging from 135 to $325 \mathrm{bp}$ were identified in 30 individuals. The $N_{\mathrm{A}}$ per locus ranged from 4 to 17, with an average of 9.9. The $H_{\mathrm{O}}$ and $H_{\mathrm{E}}$ per locus ranged from 0.2759 to 0.8621 
and from 0.4307 to 0.9177 , with an average of 0.6226 and 0.7250 , respectively. The PIC of these molecular markers was calculated to access their usefulness (Botstein et al., 1980). One locus (SJ-45) showed moderately polymorphic $(0.25<\mathrm{PIC}<0.5)$ and nine loci were highly polymorphic (PIC $>0.5)$.

Two loci (SJ-31 and SJ-65) showed significant departure from HWE after Bonferroni corrections $(\mathrm{P}<0.005)$ (Rice, 1989), which may result from the small sample size or the presence of null alleles. The MICRO-CHECKER analysis showed no evidence for scoring error or technical or statistical artifacts (Oosterhout et al., 2004). There was no significant genotypic LD between all pairs of these loci after Bonferroni correction $(\mathrm{P}>0.005)$. These 10 sequences were further searched in GenBank using the BLASTn program, and no similar sequence was found. The information about these pairs of primers is listed in Table 2.

The applicability of these markers in a closely related species, $S$. australasicus, was evaluated. All 10 loci were successfully amplified, and nine showed polymorphisms. The $H_{\mathrm{O}}$ and $H_{\mathrm{E}}$ ranged from 0.4286 to 1.0000 and from 0.5792 to 0.9273 , respectively. The $N_{\mathrm{A}}$ per locus ranged from 5 to 16 with an average of 9.4 , and the PIC was from 0.4853 to 0.9039 . Two loci (SJ-31and SJ-78) showed to be moderately polymorphic $(0.25<\mathrm{PIC}<0.5)$ and seven loci were highly polymorphic (PIC $>0.5$ ) (Table 3 ). Six of the nine loci were detected to deviate from HWE. These microsatellite markers might be useful for detecting population genetic diversity and structure of the cross-species.

\begin{tabular}{|c|c|c|c|c|c|c|c|c|c|c|}
\hline \multirow[t]{2}{*}{ Locus } & \multicolumn{5}{|c|}{ Scomber japonicus } & \multicolumn{5}{|c|}{ Scomber australasicus } \\
\hline & $N_{\mathrm{A}}$ & $H_{\mathrm{O}}$ & $H_{\mathrm{E}}$ & HWE (P value) & PIC & $N_{\mathrm{A}}$ & $H_{\mathrm{O}}$ & $H_{\mathrm{E}}$ & HWE (P value) & PIC \\
\hline SJ-23 & 8 & 0.6207 & 0.7846 & 0.1678 & 0.7423 & 11 & 0.7500 & 0.8526 & 0.3627 & 0.8180 \\
\hline SJ-28 & 5 & 0.6552 & 0.6407 & 0.7021 & 0.5576 & 5 & 0.5714 & 0.6688 & 0.1496 & 0.5929 \\
\hline SJ-30 & 17 & 0.8276 & 0.9080 & 0.8294 & 0.8833 & 16 & 0.7143 & 0.8708 & $0.0000^{*}$ & 0.8412 \\
\hline SJ-31 & 6 & 0.5000 & 0.6156 & $0.0030^{*}$ & 0.5698 & 12 & 0.4286 & 0.5792 & 0.8051 & 0.4853 \\
\hline SJ-32 & 16 & 0.7586 & 0.8959 & 0.4965 & 0.8704 & 5 & 0.6400 & 0.8122 & $0.0000^{*}$ & 0.7805 \\
\hline SJ-42 & 7 & 0.5185 & 0.6024 & 0.9997 & 0.5152 & 14 & 0.4286 & 0.9273 & $0.0000^{*}$ & 0.9039 \\
\hline SJ-45 & 5 & 0.2759 & 0.4307 & 0.2903 & 0.3931 & - & - & - & - & - \\
\hline SJ-65 & 4 & 0.3793 & 0.5977 & $0.0000^{*}$ & 0.5193 & 6 & 1.0000 & 0.7747 & $0.0124 *$ & 0.7248 \\
\hline SJ-76 & 14 & 0.8621 & 0.8566 & 0.3894 & 0.8237 & 10 & 0.4286 & 0.8383 & $0.0000^{*}$ & 0.8011 \\
\hline $\begin{array}{l}\text { SJ-78 } \\
\end{array}$ & 17 & 0.8276 & 0.9177 & 0.0899 & 0.8939 & 6 & 0.6071 & 0.5896 & $0.0000^{*}$ & 0.4929 \\
\hline
\end{tabular}

$N_{\mathrm{A}}$, number of alleles; $H_{\mathrm{O}}$, observed heterozygosity; $H_{\mathrm{E}}$, expected heterozygosity; PIC, polymorphism information content. $* \mathrm{P}<0.005$ for significant deviation from $\mathrm{HWE}$ after Bonferroni correction.

In conclusion, 10 polymorphic microsatellite markers were developed for $S$. japonicus by the RAPD-PCR method and amplified successfully in the related species $S$. australasicus. Most of these loci show high polymorphism in S. japonicus and S. australasicus. This set of microsatellite markers should be an important supplement of former microsatellite database and should also be used for accessing population genetic diversity and individual identification of $S$. japonicus and closely related species.

\section{ACKNOWLEDGMENTS}

Research supported by the National Basic Research Special Foundation of China (\#2013FY110700), the National Science and Technology Support Plan (\#2013BAD13B05), the Special Fund for Agro-Scientific Research in the Public Interest (\#201303047), and the National Infrastructure of Fishery Germplasm Resources.

Genetics and Molecular Research 16 (3): gmr16039712 


\section{REFERENCES}

Botstein D, White RL, Skolnick M and Davis RW (1980). Construction of a genetic linkage map in man using restriction fragment length polymorphisms. Am. J. Hum. Genet. 32: 314-331.

Cha H, An H, Choi J, Kang S, et al. (2010). Erratum to: Isolation and characterization of polymorphic microsatellite markers for genetic analysis of chub mackerel (Scomber japonicus). Conserv. Genet. Resour. 2: 7-9. https://doi. org/10.1007/s12686-009-9123-7

Cheng J, Yanagimoto T, Song N and Gao TX (2015). Population genetic structure of chub mackerel Scomber japonicus in the Northwestern Pacific inferred from microsatellite analysis. Mol. Biol. Rep. 42: 373-382.

Cifarelli RA, Gallitelli M and Cellini F (1995). Random amplified hybridization microsatellites (RAHM): isolation of a new class of microsatellite-containing DNA clones. Nucleic Acids Res. 23: 3802-3803. https://doi.org/10.1093/ $\underline{\operatorname{nar} / 23.18 .3802}$

Collette BB and Nauen CE (1983). FAO species catalogue. Vol. 2. Scombrids of the world. An annotated and illustrated catalogue of tunas, mackerels, bonitos and related species known to date. FAO Fish Synop. 125: 137.

Divya PR, Vineesh N, Kathirvelpandian A, Mohitha C, et al. (2016). Identification and characterisation of microsatellite markers in narrow barred Spanish mackerel Scomberomorous commerson (Lacepede, 1800). Indian J. Fish. 63: 61-65.

Ender A, Schwenk K, Städler T, Streit B, et al. (1996). RAPD identification of microsatellites in Daphnia. Mol. Ecol. 5: 437-441. https://doi.org/10.1111/j.1365-294X.1996.tb00333.x

FAO (2010). The State of World Fisheries and Aquaculture. State World Fish. Aquacult. 49: 40-41.

Guo HP, Zhou SJ, Zhu XJ, Xu XJ, et al. (2016). Population genetic analysis of from the Qinling-Daba Mountain Areas based on microsatellite DNA. Acta Entomol. Sin. 59: 337-345.

Hua CJ and Shan LL (2004). Study on the biological characteristics and status of common mackerel (Scomber japonicus Houttuyn) fishery in the East China Sea region. Mar. Fish. 26: 73-78.

Liu YG, Bao BL, Liu LX, Wang L, et al. (2008). Isolation and characterization of polymorphic microsatellite loci from RAPD product in half-smooth tongue sole (Cynoglossus semilaevis) and a test of cross-species amplification. Mol. Ecol. Resour. 8: 202-204. https://doi.org/10.1111/j.1471-8286.2007.01923.x

Lunt DH (1999). An efficient method for PCR-based isolation of microsatellite arrays (PIMA). Mol. Ecol. 8: 891-893.

Ma HY, Ma CY, Ma LB and Cui HY (2010). Novel polymorphic microsatellite markers in Scylla paramamosain and cross-species amplification in related crab species. J. Crustac. Biol. 30: 441-444. https://doi.org/10.1651/09-3263.1

Marshall TC, Slate J, Kruuk LEB and Pemberton JM (1998). Statistical confidence for likelihood-based paternity inference in natural populations. Mol. Ecol. 7: 639-655. https://doi.org/10.1046/j.1365-294x.1998.00374.x

Matsui T (1967). Review of the mackeral genera Scmber and Rastrelliger with description of a new species of Rastrelliger. Copeia 71-83.

Mohanty P, Sahoo L, Pillai BR, Jayasankar P, et al. (2016). Genetic divergence in Indian populations of M. rosenbergii using microsatellite markers. Aquacult. Res. 47: 472-481. https://doi.org/10.1111/are.12508

Oosterhout CV, Hutchinson WF, Wills DPM and Shipley P (2004). MICRO-CHECKER: software for identifying and correcting genotyping errors in microsatellite data. Mol. Ecol. Notes 4: 535-538. https://doi.org/10.1111/j.1471$\underline{8286.2004 .00684 . x}$

O'Reilly P and Wright JM (1995). The evolving technology of DNA fingerprinting and its application to fisheries and aquaculture. J. Fish Biol. 47: 29-55. https://doi.org/10.1111/j.1095-8649.1995.tb06042.x

Qiang L I and Wan J M (2005). SSRHunter: Development of a local Searching Software for SSR Sites. Hereditas 27: 808-810.

Raymond M and Rousset F (1995). GENEPOP (Version 1.2): Population Genetics Software for Exact Tests and Ecumenicism. J. Hered. 86: 248-249. https://doi.org/10.1093/oxfordjournals.jhered.a111573

Rice WR (1989). Analyzing tables of statistical of statistical tests. Evolution 43: 223-225. https://doi. org/10.1111/j.1558-5646.1989.tb04220.x

Sun Y, Sun H, Qian G, Zhao Y, et al. (2009). Isolation and characterization of microsatellite loci in the freshwater crab Sinopotamon yangtsekiense and cross-species amplification in related taxa (Decapoda: Brachyura). J. Crustac. Biol. 29: 413-418. https://doi.org/10.1651/08-3115.1

Tan MP, Jamsari AFJ and Siti Azizah MN (2016). Genotyping of microsatellite markers to study genetic structure of the wild striped snakehead Channa striata in Malaysia. J. Fish Biol. 88: 1932-1948. https://doi.org/10.1111/jfb.12956

Tang CY, Tzeng CH, Chen CS and Chiu TS (2009). Microsatellite DNA markers for population-genetic studies of blue mackerel (Scomber australasicus) and cross-species amplification in S. japonicas. Mol. Ecol. Res. 9: 824-827.

Utter FM (2006). Biochemical genetics and fishery management: an historical perspective. J. Fish Biol. 39: 1-20. https:// doi.org/10.1111/j.1095-8649.1991.tb05063.x

Genetics and Molecular Research 16 (3): gmr16039712 
Weber JL and May PE (1989). Abundant class of human DNA polymorphisms which can be typed using the polymerase chain reaction. Am. J. Hum. Genet. 44: 388-396.

Zeng L, Cheng Q and Chen X (2012). Microsatellite analysis reveals the population structure and migration patterns of Scomber japonicus (Scombridae) with continuous distribution in the East and South China Seas. Biochem. Syst. Ecol. 42: 83-93. https://doi.org/10.1016/j.bse.2012.02.014

Genetics and Molecular Research 16 (3): gmr16039712 